\title{
Taste and flavour perceptions of glucosinolates, isothiocyanates, and related compounds
}

Article

Accepted Version

Bell, L., Oloyede, O. O., Lignou, S., Wagstaff, C. and Methven, L. (2018) Taste and flavour perceptions of glucosinolates, isothiocyanates, and related compounds. Molecular Nutrition \& Food Research, 62 (18). 1700990. ISSN 1613-4125 doi: https://doi.org/10.1002/mnfr.201700990 Available at https://centaur.reading.ac.uk/76654/

It is advisable to refer to the publisher's version if you intend to cite from the work. See Guidance on citing.

Published version at: http://dx.doi.org/10.1002/mnfr.201700990

To link to this article DOI: http://dx.doi.org/10.1002/mnfr.201700990

Publisher: Wiley

All outputs in CentAUR are protected by Intellectual Property Rights law, including copyright law. Copyright and IPR is retained by the creators or other copyright holders. Terms and conditions for use of this material are defined in the End User Agreement.

www.reading.ac.uk/centaur 
Central Archive at the University of Reading

Reading's research outputs online 


\title{
Taste and Flavour Perceptions of Glucosinolates, Isothiocyanates,
}

\section{and Related Compounds}

\author{
Luke Bell, Omobolanle O. Oloyede, Stella Lignou, Carol Wagstaff, Lisa Methven \\ University of Reading, Department of Food \& Nutritional Sciences, Whiteknights, Reading, \\ Berkshire, UK. RG6 6AP
}

\begin{abstract}
Brassicaceae plants are renowned for their taste, aroma and trigeminal characteristics; predominantly bitter taste, sulfurous aroma and pungency. Compounds responsible for these sensations include the glucosinolates (GSLs) and their hydrolysis products, particularly isothiocyanates (ITCs), but also sulfur-containing volatile compounds. This article reviews the relative importance of taste and flavour perceptions resulting from such compounds; collating evidence from papers where findings are based on sensory analytical correlations, and those that have extracted specific compounds prior to sensory evaluation. Where specific GSLs impart bitterness and many ITCs impart pungency, this is clearly not true for all GSLs and ITCs. Designing crop improvement strategies for sensory traits based on total GSL content would be flawed, as it does not consider the relative differences in sensory characteristics of different GSLs and ITCs, nor contribution from other GSL hydrolysis products. In addition, some Brassicaceae plants are consumed raw, whilst others are cooked; this affects not only the hydrolysis of GSLs, but also the generation and release of sulfides. Therefore, in breeding new
\end{abstract}

Received: 29-Nov-2017; Revised: 05-Feb-2018; Accepted: 13-Feb-2018

This article has been accepted for publication and undergone full peer review but has not been through the copyediting, typesetting, pagination and proofreading process, which may lead to differences between this version and the Version of Record. Please cite this article as doi: 10.1002/mnfr.201700990. 
plant varieties it is prudent to consider the individual GSLs, the typical cooking conditions the plant is subjected to, enzyme stability, and resultant composition of both GSL hydrolysis products (including ITCs) and sulfides.

Keywords: taste, aroma, pungency, glucosinolate, isothiocyanate, sulfide

\section{List of abbreviations:}

AEDA - Aroma Extract Dilution Analysis

AITC - Allyl Isothiocyanate

ATC - Allyl Thiocyanate

AVI - Alanine Valine Isoleucine

BITC - Benzyl Isothiocyanate

DHE - Dynamic Headspace Extraction

DMB - Dimeric 4-mercaptobutyl

DMDS - Dimethyl Disulfide

DMS - Dimethyl Sulfide

DMTS - Dimethyl Trisulfide

ESP - Epithionitrile Specifier Protein

GS-MS - Gas Chromatography Mass Spectrometry

GC-O - Gas Chromatography Olfactometry

GSL - Glucosinolate

This article is protected by copyright. All rights reserved. 
HPLC - High Pressure Liquid Chromatography

ITC - Isothiocyanate

LC-MS - Liquid Chromatography Mass Spectrometry

MTBITC - 4-methylthiobut-3-enyl Isothiocyanate

NSP - Nitrile Specifier Protein

OAV - Odour Activity Value

OR - Olfactory Receptor

PAV - Proline Alanine Valine

PCA - Principal Component analysis

PEITC - Phenethyl Isothiocyanate

PLS - Partial Least Squares

PROP - 6-n-propylthiouracil

PTC - Phenylthiocarbamide

SAFE - Solvent Assisted Flavour Extraction

SBSE - Stir-bar Sorptive Extraction

SF - Sulforaphane

SMCSO - S-methyl-L-cystein Sulfoxide

SNP - Single Nucleotide Polymorphism

SPE - Solid Phase Extraction

SPME - Solid Phase Microextraction

This article is protected by copyright. All rights reserved. 
SVOC - Sulfur-containing Volatile Organic Compound

TFP - Thiocyanate Forming Protein

TRP - Transient Receptor Potential

VOC - Volatile Organic Compound

\section{$1 \quad$ Introduction}

Glucosinolates (GSLs) are secondary defense metabolites present within the Brassicaceae family of plants. They are $\beta$-thioglucoside- $N$-hydroxysulfates containing an amino acid derived side chain (R; see Figure 1). The structures and hydrolysis of GSLs have previously been reviewed by Holst and Williamson [1]. GSLs are held within organelles in the plant cytoplasm, whereas myrosinase enzymes that hydrolyze these compounds are situated in the vacuole. When tissues are damaged, by cutting or mastication, hydrolysis can lead to the generation of numerous degradation products, which include isothiocyanates (ITCs) and other compounds, such as indoles and thiocyanates [1] (Figure 1; [2, 3]). The final product composition depends greatly upon $\mathrm{pH}$ and temperature conditions. Myrosinase enzyme is required for primary hydrolysis of GSLs, however products can be further modified by specifier proteins, such as epithiospecifier protein (ESP), nitrile specifier protein (NSP), and thiocyanate formation protein (TFP) [4, 5]. ESP is a cofactor of myrosinase that promotes the formation of epithionitriles and nitriles from GSLs with a terminal double bond. Where ESP is intact, there is a tendency for greater nitrile production and reduced ITC production; the reverse occurs where ESP is denatured, by mild temperature cooking, for example [6].

Throughout the scientific literature, it is generally accepted that GSLs and ITCs contribute towards the distinctive tastes and flavours associated with Brassicaceae plants [7]. However, there is relatively little evidence relating taste and aroma perception to individual compounds, and few studies compare the relative effects of GSLs and ITCs alongside other phytochemical components; or

This article is protected by copyright. All rights reserved. 
investigate the extent of interactions between such compounds on sensory perception. In particular, the relative importance of the ITC degradation products and sulfur-containing volatile organic chemicals (VOCs) is not well understood.

It is accepted that bitterness is one of the key attributes associated with Brassicaceae plants, and is proposed to result from GSLs and ITCs [8]. Numerous studies have indicated that consumer preference and choice of vegetables in the diet is in part determined by taste sensitivity to bitter compounds [9]. It is therefore important to understand how individual compounds contribute towards sensations of taste, aroma and trigeminal sensations (such as pungency) in order to encourage greater consumption of Brassicaceae vegetables. ITCs and indole degradation products are well known for their health beneficial properties [10-16] (Table 1). This is primarily due to anti-carcinogenic activity and chemoprotective mechanisms, and prevention of cardiovascular and neurodegenerative disorders [7, 17]. It is therefore beneficial to understand what tastes and flavours GSLs/ITCs impart, and how they can be modulated without increasing unpleasant sensations and reducing consumer acceptability.

Some authors have argued that good taste and health benefits in a Brassicaceae crop product are incompatible goals [9]. However, as will be explored in this review, some potent health beneficial GSL and ITC compounds have no distinct or objectionable taste. Furthermore, those compounds with bitter attributes can be masked to a degree by other mechanisms. This can be achieved primarily through plant breeding and selection to modify phytochemical constituents of crops - a practice that, somewhat ironically, has traditionally been employed to remove bitter and unpleasant tasting compounds from cultivars, and increase sweetness. This has been largely due to safety concerns, rather than being consumer driven [9]. It is arguable that many of these practices may have been misguided or unnecessary, particularly in the case of GSLs and ITCs within human food crops, as healthy humans generally tolerate these with no adverse health effects [18].

We aim to draw together information relating to the taste and flavour perceptions of GSL, ITC, and related VOC compounds, both in isolation, and within the food matrix. We will discuss how these perceptions are modified according to human genotype, and describe the mechanisms

This article is protected by copyright. All rights reserved. 
responsible. We will highlight compounds of interest for future study, as well as evaluate the methods employed to link compounds with sensory perceptions.

\section{Methods of associating taste and flavour with specific compounds}

\subsection{Chemical extraction \& analysis}

GSLs, as non-volatile compounds, are usually extracted from ground plant material in aqueous methanol, then identified and quantified by LC-MS [19]. Relating GSL type and concentration to bitter taste is then often done through correlating changes to sensory data [20-22]. However, such correlations can be misleading, and in order to confirm the contribution of GSLs and/or ITCs, to taste perception food grade extraction and fractionation is required to provide pure isolates for human testing. This can be done through ethanol extraction and semi-preparative HPLC, using water and ethanol as solvents, as described by Zabaras et al. [23] in their characterisation of taste-active extracts from raw Brassica vegetables.

Analytically, volatile flavour compounds can be extracted using solvents (solvent-assisted flavour evaporation; SAFE), headspace techniques such as solid phase micro extraction (SPME), dynamic headspace extraction (DHE), or solid phase extraction (SPE) for the analysis of more polar compounds in low fat foods $[24,25]$. Extracted compounds can then be identified and quantified using gas chromatography mass spectrometry, and assigned an odour characteristic by employing GColfactometry (GC-O) [24, 26, 27], or by presentation of isolated compounds to sensory assessors. This can be a challenging process, requiring a high degree of optimization for the foodstuff in question [28]. It also relies upon adequate compound library identifications or reference standards, which for some compounds are not readily available or affordable. Identification alone does not indicate whether a volatile compound has any impact on the flavour of a sample; odour impact compounds are usually denoted by odour activity values (OAVs), which are calculated as the ratio between the

This article is protected by copyright. All rights reserved. 
concentration of the aroma compound in each respective food sample matrix, and its sensory threshold concentration, which has usually been measured in water [26, 29].

\subsection{Sensory analysis and relating analytical and sensory data}

How individual GSL, ITC, or other compounds are perceived (if at all) within a whole food matrix is, however, a very different question to asking how pure compounds are perceived when provided individually to human subjects. There are many different factors that will contribute towards perception, such as the relative concentrations of volatile compounds (i.e. the overall flavour composition), if they degrade quickly, if processing modifies them, or if they act in competition for specific olfactory or taste receptors. Typically, sensory panels are used to evaluate and score foods according to the intensity of sensory perceptions (bitter, sweet, sour, salty, pungent etc.). Such sensory data can be correlated to chemical data using Principal Component Analysis (PCA) or Partial Least Squares regression (PLS) [30, 31]. This produces a separation within a multidimensional space where associations between sensory and chemical data can be inferred and assigned levels of significance or relatedness.

Humans are typically poor at distinguishing between multiple compounds within a mixture, as these are 'combined' by the brain to form a different sensation that would otherwise be perceived if each of the compounds was sampled individually. Studies that have reconstituted taste and flavours have illustrated that characteristic 'profiles' associated with foods and beverages are a result of complex interactions between volatile components, as well as with non-volatiles [32]. It is for this reason therefore, that correlation analyses be interpreted cautiously, as these do not necessarily reveal a complete picture of taste and flavour generation on a molecular level. All food samples are composed of many different tastes and volatile aromas ('natural mixtures'), and humans vary in their ability to detect, identify, describe, and cognitively 'separate' these from each other [33, 34]. Many of the compounds found in Brassicales crops are likely to act synergistically to create distinctive flavours; however due to the lack of available food grade ITC, thiocyanate, nitrile, and indole standards, this hypothesis has never been tested.

This article is protected by copyright. All rights reserved. 
In some Brassicales crops, GSL compounds are significantly associated with bitterness [20], but in others no significant relationships have been determined [21]. Such lack of consensus between studies may be indicative of the effects that different preparation and cooking procedures have on bitter-producing compounds. However, as ITCs and/or nitriles are rarely quantified in such studies, it is not explicitly clear whether it is the precursor or hydrolysis products that are the predominant cause of the presence/absence of bitter sensations, or if they both infer independent sensory properties. Often, GSLs are used as a proxy measurement for hydrolysis products, and correlations (or their absence) with sensory traits (such as bitterness) are often conflated with each other. Caution must be taken in the interpretation of such analyses, as correlation $\neq$ causation. For example, some GSLs may hypothetically correlate with pungency, but it is not the GSLs themselves that cause this sensation (Table 1).

Baik et al. [21] analysed the GSL content of 19 broccoli cultivars to determine any associations with sensory traits. Broccoli (Brassica oleracea var. italica) does not contain high concentrations of GSLs that produce pungent or acrid ITCs (e.g. sinigrin, gluconapin, glucobrassicanapin, gluconasturtiin [35]), and so it was therefore unsurprising that GSLs alone did not overtly contribute significantly to the overall taste profile. The major GSL constituent of broccoli is glucoraphanin, which is thought to have little perceptible taste (however no known studies have isolated and explicitly tested this compound, to our knowledge). The authors (Baik et al. [21]) concluded that sulfides and other VOCs contributed more to the taste and flavour than GSLs. Cartea et al. [36] also drew similar conclusions: that GSLs and their breakdown products do not contribute significantly to taste and aroma of broccoli cultivars. It is however possible that GSLs and ITCs may be perceptible at very low concentrations and do contribute more than has been previously realised. Until adequate studies are conducted to ascertain the detection thresholds of these compounds, much of the discussion found in such papers will remain conjecture.

In neither of the aforementioned studies were ITCs, nitriles, or other hydrolysis products quantified, and so the lack of correlations between GSLs and sensory attributes is not the same as 
there being no correlations between GSL hydrolysis products and sensory attributes. GSLs are not indicative of hydrolysis product type or abundance, and are merely a convenient proxy for the types that may be produced under certain conditions [37]. In order to determine this properly, dedicated analyses of ITCs and nitriles should be performed alongside GSL analysis. More thorough investigation into the tastes, flavours and abundances of hydrolysis products is needed before conclusions can be drawn of whether GSL content is unimportant for sensory attributes. In one of the few studies to have isolated and tasted non-volatile fractions from Brassica vegetables, several compounds within each extract were found to contribute to the bitterness (such as phenolics), and neither total nor individual GSL content alone could fully explain the perceived bitterness [23]. This may only be applicable to Brassica oleracea however, as many other species have very different GSL and ITC profiles. Exploration of other diverse species and genotypes will determine the impact of these compounds on sensory traits within their own respective food matrices.

\section{$3 \quad$ Bitter taste of glucosinolates and isothiocyanates}

\subsection{General}

The presence of some intact GSLs is commonly associated with bitter sensations within the literature. From an evolutionary perspective, humans have evolved to be sensitive to bitter compounds and to broadly reject them when perceived to be excessive. In terms of survival, this is an essential protective mechanism to prevent poisoning. Alkaloids, phenols, flavonoids, terpenes, isoflavones and oxazolidines are all known to have bitterness associated with them, and all are present in the human diet; but they are also known to be toxic (in some form) in high doses [9]. It is interesting therefore that Brassicaceae crops have become so popular across the globe, despite their containing these bitter phytochemicals.

\subsection{Human bitter taste perception and consumer acceptance}

This article is protected by copyright. All rights reserved. 
Humans detect bitterness as (arguably) a uniform sensation; this is despite the fact that many different compound classes interact with many different taste receptors to construct bitter sensation [38]. To complicate matters further, intensity of perception also varies with age; being greater in infants and children, and much reduced in the elderly [39].

The predominant mode of action is via compound interaction with G-proteins coupled with TAS2R taste receptors on the tongue (Figure 2). Due to genetic linkage and recombination, humans have a diverse array of genotypes for any given taste receptor; being either homozygous (containing either two functioning or two non-functioning copies of a gene) or heterozygous (containing one functioning and one non-functioning copy). Such haplotypes can give rise to different phenotypes; sometimes referred to as "supertaster", "medium taster", or "non-taster", for any given receptor [9]. Differences in intensity of taste perception may influence liking, and consequently, consumption of bitter tasting foods such as Brassicas [40].

Bitter "blindness" or "non-tasters" to the synthetic compounds 6-n-propylthiouracil (PROP) and phenylthiocarbamide (PTC) is well documented. These compounds contain a thiourea group, which is also present in GSLs and ITCs, and preferentially bind to the T2R38 bitter taste receptor [49]. Bitterness sensitivity to such compounds has been linked to the Mendelian inheritance of TAS2R38 haplotypes. Three functional single nucleotide polymorphisms (SNPs) within the TAS2R38 gene encode amino acid substitutions which result in two common haplotypes: Pro-Ala-Val (PAV), the dominant (sensitive) variant, and AVI (Ala-Val-Ile), the recessive (insensitive) one [41]. Previous papers have found PAV/PAV individuals to rate bitter intensity of Brassicaceae vegetables significantly higher than AVI/AVI individuals $[42,43]$. Bitter sensitivity is also influenced by receptor cell abundance, a surrogate marker for which is fungiform papillae density (FPD) on the tongue. Therefore, the extent of bitter response of PAV/PAV individuals to Brassicaceae vegetables will be modulate by FPD.

Some research has shown that this does not necessarily translate into whether an individual will base their liking upon this sensitivity however [44]. A study by Bell et al. [45] which determined

This article is protected by copyright. All rights reserved. 
TAS2R38 diplotypes of 69 individuals reported that "supertaster" status did not have a significant impact upon liking of different rocket salad accessions. There was a general trend observed that "nontasters" liked the taste of leaves more overall, but this was not significantly different from either "supertasters" or "medium tasters". Similar observations were made in broccoli and white cabbage by Shen et al. [43], where it was suggested that liking was also determined by numerous other factors (such as food familiarity, cultural acceptance, fungiform papillae density, and the genotype of other TAS2R receptors).

\subsection{Glucosinolate bitterness}

Compounds such as sinigrin, gluconapin, progoitrin and indole GSLs (glucobrassicin, neoglucobrassicin) are cited as imparting bitterness in crops such as broccoli, and other varieties of Brassica oleracea $[40,46-48]$, however this effect is not universal, as taste panelists do not uniformly detect or describe these as bitter in isolation (Table 1) [22]. This suggests that some individuals may be "non-tasters" or "bitter blind" for these GSL compounds, as with PROP and PTC.

In Brussels sprouts, high sinigrin and progoitrin concentrations have been linked with consumer rejection and poor taste [50]. The threshold of detection for sinigrin has been reported as low as $106 \mathrm{mg} . \mathrm{L}^{-1}$, and goitrin (the main progoitrin hydrolysis product; 5-vinyloxazolidine-2-thione) $12 \mathrm{mg} . \mathrm{L}^{-1}$ [22], but values for other GSLs and hydrolysis products are scarce in the literature. This is perhaps in part due to the lack of affordable standards in quantities larger than a few milligrams, and the difficulty in isolating compounds to a food grade standard. The extreme bitterness of goitrin (Table 1) is perhaps linked with its reported toxic effects in individuals who are iodine deficient or thyroid impaired. The compound can cause the condition known as goiter, where it acts as an iodine competitor, and thus can inhibit uptake. There is little evidence for this compound being linked with illness in otherwise healthy individuals however [51].

In both Diplotaxis tenuifolia and Eruca sativa, which are commonly referred to as 'wild rocket' and 'salad rocket' respectively, the compounds progoitrin and dimeric-4-mercaptobutyl GSL 
(DMB) have also been associated with bitter taste [52]. It has been reported that the presence of some GSLs contributes to a pleasant or distinct taste to certain cultivars of rocket. Both Bell et al. [30] and D'Antuono et al. [53] reported that the presence of 4-hydroxyglucobrassicin (an indolic GSL) within rocket leaf tissues was associated with such pleasant traits, and Bell et al. [45] also reported that relatively 'minor' GSLs contributed towards increased liking for a subset of consumers.

\subsection{Isothiocyanate bitterness}

Due to the various factors involved in GSL hydrolysis product formation, and the efficiency of myrosinases under differing $\mathrm{pH}$, ionic, and temperature conditions, it is not certain that ITCs will be produced [54]. In some Brassicaceae crops nitriles are the predominant breakdown product, not ITCs; such as in white cabbage (B. oleracea var. capitata) [37]. It is unknown how ITC-nitrile ratios affect perceptions of bitterness, or indeed if nitriles and other degradation products are bitter tasting too. Studies report nitriles being present in solid phase micro-extraction (SPME) experiments, but olfactometry has not been performed adequately to determine any flavour attributes [55].

In studies that have quantified GSLs and ITCs separately, correlation analyses indicate that some specific compounds individually contribute to bitterness, and others do not [30]. Such evidence supports particular compounds leading to bitter traits, but stops short of establishing a causal link. It is highly probable that some ITC compounds may be perceived as more bitter (and/or pungent) than others, but the scarcity of food grade standards for such compounds makes testing such hypotheses difficult.

\subsection{Non-bitter glucosinolates and isothiocyanates}

Some GSL compounds, such as glucoraphanin, have been consistently noted for the lack of significant association with bitterness in vegetable tissues. The ITCs and degradation products of glucoraphanin and glucoiberin are only semi-volatile, and so are unlikely to contribute overtly to the flavour of crops such as broccoli [56]. Breeders have taken advantage of this aspect of the chemistry to increase glucoraphanin concentrations within new cultivars and varieties such as Beneforté [57].

This article is protected by copyright. All rights reserved. 
Bell et al. [45] noted that neither glucoraphanin or glucoerucin shared any significant correlations with bitterness or consumer acceptance/rejection in rocket salad. The health benefits associated with glucoraphanin and its ITC sulforaphane (SF), are well documented in the literature, and could therefore be selectively enhanced without significant increases in bitterness [30, 46].

\section{$4 \quad$ Pungency of isothiocyanates}

\subsection{Human pungency perception}

A key attribute of ITC compounds is the pungent or burning sensation that is caused upon consumption (Table 1). This is due to interaction with pain receptors feeding into the trigeminal nerve, and is distinct from flavour and taste (Figure 2) [28]. These trigeminal nerve endings within the mouth, nose and eyes also convey inflammatory and thermal stimuli to the brain. ITCs achieve such trigeminal stimulation by activating transient receptor potential (TRP) ion channels [58]. Allyl ITC (AITC), benzyl ITC (BITC) and phenethyl ITC (PEITC; Figure 1) have all been shown to activate the ANKTM1 TRP ion channel within mammalian cells, which has also been linked with the burning perception of noxious cold. Other pungent chemicals, such as capsaicin (from chili peppers), also interact with this ion channel family, and induce inflammatory responses in addition to the perception of intense heat [58].

\subsection{Isothiocyanate compounds}

In terms of plant defense, ITCs dissuade herbivores and reduce insect proliferation as a result if no other feed source is available [59]. AITC is perhaps the best-studied ITC compound, and is well known for its hot, lachrymose, and pungent effects in crop species such as mustards (Brassica juncea, and Brassica nigra), horseradish (Armoracia rusticana) and wasabi (Eutrema japonicum; Table 1). These properties have led to the prevalence of these crops as the main ingredient in condiment sauces in various cultures across the world; mustards and horseradish are common in European cuisine, and wasabi paste is widely used in Japanese dishes such as sushi $[55,60,61]$.

This article is protected by copyright. All rights reserved. 
Wasabi is perhaps the most infamous pungent Brassicaceae crop, known for its intense lachrymose effects when eaten. The ITCs of glucocapparin (methyl ITC), glucoputranjivin (isopropyl ITC), sinigrin (AITC), gluconapin (3-butenyl ITC), and glucobrassicanapin (4-pentenyl ITC) have all been identified within wasabi roots, and all are described as having pungent or acrid flavours and aromas [62] (Table 1). In horseradish by contrast, the pungency of ITCs has also been interpreted as spicy, or even as imparting a "cooling" sensation on the palate. This is a descriptor that at first seems unlikely, yet the function of ANKTM1 TRP ion channels also serves as a means of detecting noxious cold, and so ITCs could be interpreted this way by the brain [58].

Horseradish root is commonly added to fermented foods in Eastern Europe, as well as to bread as flavouring. It may even be added to drinks, such as the "Bloody Mary", as a substitute for Tabasco sauce. The spiciness of horseradish is a fundamental component of its uses and, generally, the more pungent it is the better from a culinary perspective [61]. A study by D'Auria et al. [63] showed that pungency of horseradish declines after grating and during refrigeration; probably due to the cell damaged incurred and the hydrolysis of GSLs when exposed to myrosinase. Pungency can be preserved with the addition of fat or oil which limits ITC degradation [61].

In Sinapis alba (white mustard) pungency is primarily caused by 4-hydroxybenzyl ITC, the hydrolysis product of the aromatic GSL glucosinalbin. This compound can cause intense burning sensations that are overwhelming for many people; however the trait is considered enjoyable to mustard consumers after a period of familiarization [64]. Another pungent compound that is less well known and studied is raphasatin (4-methylthio-3-butenyl ITC; MTBITC), the ITC of glucoraphasatin (also known as dehydroerucin) [65]. This compound is abundant in radish species (Raphanus spp.) and is especially strong in varieties such as daikon white radish [66]. The degree of pungency of roots is linked to growth season, and is highly dependent upon environmental factors [67].

This article is protected by copyright. All rights reserved. 


\subsection{Consumer acceptance of pungency}

Pungency has been linked with improved consumer acceptance of radish in some cohorts $[65,68]$. Wills \& Coogan [68] demonstrated that different cultural populations find the pungency of radish, and the ITC raphasatin, to be more acceptable than others. A Japanese cohort (who would be more familiar with radish in traditional dishes) preferred the pungent sensations, whereas an Australian cohort broadly rejected the sensation. There is evidence to suggest that taster status for genes such as TAS2R38 differ between ethnic groups. Populations of Asian descent typically have fewer bitter nontasters (to PROP and PTC) than Caucasians and South Asians, for example [69]. This is somewhat contrary to what one would expect (as bitterness in Brassicaceae is typically regarded as a negative trait), but Asian populations generally have a much larger amount of these crops in their diets than other populations. This is evidenced by reduced breast cancer risk in Asian populations compared with Western, and due to the higher abundance of ITCs present [70]. It is however unknown how olfactory receptor (OR) gene haplotypes differ between ethnic populations, and therefore it is unknown if this is also a factor in determining the liking of pungency in cultures where such sensations are common.

This perhaps demonstrates the difficulty faced by plant breeders in producing new cultivars with improved sensory traits: what one population prefers may be completely rejected by another, and for completely different reasons. It may therefore be prudent for breeders to produce multiple varieties suited to the tastes of different populations or markets, rather than having a "one-size-fits-all" approach. As repeated exposure to sensory signals generally increases liking, this also paves the way for varieties increasing in strength; allowing for the developing tastes of consumers - a commercial strategy that has been adopted by chilli marketeers.

Bell et al. [45] noted that 'hotness' (pungency) of salad rocket leaves negatively impacted the liking of a large proportion of consumers. They identified three consumer clusters with varying reasons for their liking/disliking of the accessions tested: many preferred milder and sweeter leaves (but were generally accepting of all types; $46.3 \%$ ), while only a comparative minority preferred the

This article is protected by copyright. All rights reserved. 
hot and peppery leaves (22.4\%). The last group broadly rejected all of the samples presented, but slightly favored those that were milder (31.3\%). In this instance, it was pungency that was the basis for consumer liking, and not bitterness.

In other species, pungency is not a desirable trait. Papaya fruit contains glucotropaeolin, and its ITC (BITC) is noted for creating unpalatable flavour which can be disliked by consumers [71]. The same is true of watercress, where excess concentrations of PEITC can lead to increased pungency and consumer rejection [72]. Further, detailed consumer studies of other Brassicaceae are needed in order to properly determine preferences and the concentrations at which pungency becomes unpalatable.

\section{$5 \quad$ Flavour of isothiocyanates}

\subsection{General}

Whereas pungency is a trigeminal sensation, isothiocyanates in mustard, radish, and other pungent Brassicaceae can be described as flavours or aromas that are perceived by olfactory receptors (OR); Figure 2). Humans are known to have around 400 genes encoding OR [73], meaning that there are far more receptors dedicated to the sense of smell than there are to taste. There are a few known individual differences in the perception of some odours caused by genotypic variation; for example $\beta$ ionone can be perceived as either floral or sour according to a genetic variation in OR5A1, and the ability to detect green aroma from 3-hexen-1-ol is affected by the genotype of OR2J3 [74, 75]. However, other aroma characteristics are (thought to be) perceived consistently cross a population. Some authors have reported that the amount of genetic variance reported for some ORs in the ability to perceive certain odours is low, suggesting that many aromas and flavours are not perceived differently between individuals [73]. However, Keller et al. [76] demonstrated that SNPs in genes encoding human odourant receptors partly accounted for variation in odour perception between individuals, and other authors have reported that there are substantial copy number variants in ORs, suggesting that variation in odour perception (interpretation or intensity) may be greater than we are

This article is protected by copyright. All rights reserved. 
currently aware of [77]. It is thus far unreported whether the ability to perceive the smell of certain ITCs is heritable or not. It is proposed that most odours are perceived through a pattern recognition system, where a single compound can bind with different affinities to more than one OR [78]; however the specific OR(s) which respond to ITCs are as yet unreported.

The intensity of ITC flavours and aromas in radish, mustard, horseradish and wasabi are often conflated with the intense trigeminal pungency they also produce. These attributes are more subtle and easier to 'separate' cognitively in species of rocket (Eruca sativa and Diplotaxis tenuifolia [79]) and watercress (Nasturtium officinale [80]), where pungency is not as intense. The intensity of ITC flavour strength has been linked with agronomic practices, such as the application of nutrient sulfur in radish [81], and may be an agronomic means of increasing pungency without intensive breeding in the short term.

Typical flavours of Brassicaceae have traditionally been linked with GSLs and their hydrolysis products, such as sinigrin, glucoiberin and glucoraphanin [82]. Some studies have reported that a higher GSL content is associated with stronger flavour in crops such as broccoli [82], however above a certain threshold, GSL and ITC content can become detrimental to consumer acceptance [45, 82]. As will be discussed, not all ITCs contribute equally to flavour profiles; nor indeed are peppery, sulfurous, mustard and burnt flavours exclusively produced by these compounds.

\subsection{Flavours associated with pungency}

The plant genus Lepidium contains species commonly known as pepperwort, peppercress and peppergrass (and colloquially in New Zealand as Cook's Scurvy grass). Unsurprisingly, this is because of the plants' flavour and the ITC compounds they contain (Table 1). Sansom et al. [83] performed informal sensory evaluations of dried Lepidium species powders, determining that the predominant ITC responsible for the "wasabi-like" flavour of leaves is 3-butenyl ITC (3BITC; hydrolysis product of gluconapin). The Lepidium species tested contained diverse GSL profiles, including sinigrin, glucotropaeolin, glucosinalbin, glucolimnathin, glucocochlearin, and 
glucoputranjivin. The ITC products of these latter three compounds in particular are not well studied from a sensory perspective, and further study is needed to elucidate their contribution to the overall flavour profiles of these species and other crops. Ezo-wasabi (Cardamine fauriei) is another such example, which contains similar "wasabi-like" flavour attributes [84].

The presence of ITCs is regularly linked with peppery and mustard characteristics of the leaf flavour profiles of rocket (Table 1). Until relatively recently this was merely speculation [85, 86], with virtually no experimental evidence to link ITC compounds to this attribute. Bell et al. [87] identified a compound within the headspace of rocket, which was later associated with pungent odour, sulfur and mustard flavours [30]. This compound was incorrectly identified, but follow-up work by Raffo et al. [88] confirmed it to be the ITC of glucosativin (sativin; 4-mercaptobutyl ITC) [89]. Odour extracts confirmed this compound to be responsible for the typical rocket aroma that is experienced when leaves are crushed or chewed.

\subsection{Radish-like flavour}

Erucin was characterised in rocket by Raffo et al. [88] as having a 'radish' aroma; it is unknown what olfactory receptor(s) is/are responsible for this sensation. The lower relative intensity of this compound and SF in isolation, compared to sativin, may explain why they are generally imperceptible to sensory assessors within the whole tissue matrix during mastication. Phenethyl ITC (PEITC) has also been described as having a radish-like flavour in low concentrations. It is likely that ITCs in lower abundance in pungent crops such as horseradish and wasabi subtly determine flavour [60,90], and this may also vary significantly according to cultivar.

\subsection{Determination of relative flavour contribution}

As pointed out by Raffo et al. [88], the method of extraction and its duration seems to affect both the abundance and the suggested contribution of specific ITC compounds to the overall aroma. The variety of methods used to extract and characterise VOCs (GC-O, Aroma Extract Dilution Analysis; AEDA, Headspace-SPME, Stir-bar Sorptive Extraction; SBSE) by Raffo et al. [88] demonstrated this

This article is protected by copyright. All rights reserved. 
to great effect. Future studies on VOCs and ITCs should therefore be mindful of these experimental factors (such as extraction efficiency; as determined by the polarity of the compounds of interest) as these could inadvertently bias the relative compound intensities reported to be responsible for perception of a particular attribute.

The strategy of performing multiple extracts and aroma analyses as set out by Raffo et al. [88] may give the best overall representation of ITC and VOC contributions to flavour and aroma of Brassicaceae species. As they highlighted, multiple cultivars should be analysed to determine the genotypic variability and abundance of odour-active compounds. This could also feasibly be linked to genetic components, and therefore allow selection for improved flavour and aroma traits with a high degree of specificity.

6

\section{Glucosinolate and isothiocyanate sensory relationships with sweetness}

\subsection{Free sugars}

Several studies have observed that an increase in the abundance of free sugars (e.g. glucose, fructose, galactose, sucrose) within tissues confers a reduction in the intensity of bitterness [23] and also influences aftertaste [91]. The bitterness of Brussels sprouts is offset by perceptions of sweetness, for example [50], and sensory analyses of cauliflower have shown that sweet-tasting compounds modulate bitter perception [40]. This has led to the hypothesis that cultivar taste can be modified through manipulation of sugar-GSL/ITC ratios [46]. As pointed out by Padilla et al. [92], cultivars can have varying concentrations of GSLs (high or low) but are perceived as being just as bitter as one another. The important question then is to determine if other compounds or hydrolysis products cause this, and/or if the ratio with free sugars influences this perception.

It is interesting to note that cultivars of green and purple cauliflowers are known not to have the characteristic bitterness of the regular white variety. Instead, green and purple cauliflowers have a sweet, mild and 'nutty' profile [71]. A study by Schonhof et al. [20] compared the sensory profiles of

This article is protected by copyright. All rights reserved. 
white, Romanesco ('pyramidal'), green, and purple cauliflower cultivars. Analysis of GSL and sugar profiles showed that there were large differences in the sensory properties of each according to the relative abundances of alkenyl GSLs (e.g. sinigrin, gluconapin, progoitrin), indole GSLs (glucobrassicin, neoglucobrassicin, 4-hydroxyglucobrassicin, and 4-methoxyglucobrassicin), and sucrose concentrations. Consumers generally preferred the cultivars with brighter colours (green and purple) and those that had fewer of the aforementioned bitter tasting GSLs. The coloured cauliflower types were higher in glucoraphanin, but lower in glucoerucin compared to the conventional white variety. All of the cauliflower cultivars were lower in abundance for glucoraphanin compared to broccoli however. Interestingly, neither of these GSLs was strongly associated with bitterness.

The authors suggested that the modification of sugar profiles to counteract bitterness created by GSLs is a strategy for increasing consumer acceptance and enhancing the amounts of GSLs/ITCs/indoles within the diet. The trend for species belonging to a single genus, and cultivars within a single species, to have different taste and flavour profiles to mainstream crops is also apparent in rape kale (B. napus var. pabularia; "nabicol" and "couve nabica" cultivars), which are also said to be less bitter than conventional kale (B. oleracea var. acephala) $[36,71]$.

\subsection{Free amino acids}

It has been hypothesised that free amino acid concentrations within plant material may also modulate perception of bitterness and pungency. Bell et al. [30] observed that accessions of rocket salad were perceived to be less bitter and pungent where concentrations of free amino acids were higher.

Compounds such as alanine, threonine, serine and proline are known to infer sweetness in foodstuffs [93, 94]. Park et al. [95] observed that glycine and alanine contributed to sweetness in inbred cabbage lines, and that valine and leucine infer bitter tastes. Some authors have even suggested that the primary cause of bitterness in mizuna (B. juncea var. japonica) leaves comes from low concentrations of L-glutamine and L-asparagine, and high concentrations of malic acid, and is not GSL or ITC-derived, despite the presence of AITC [96]. Further research is needed to adequately

This article is protected by copyright. All rights reserved. 
determine the effects of free amino acids on Brassicaceae taste and flavour profiles, and to separate their relative effects in relation to GSL/ITC derived bitterness.

\section{Contribution of sulfur-containing volatile organic compounds to the taste of}

\section{Brassicaceae}

\subsection{Nitriles and sulfur-containing VOCs}

The aforementioned sensory attributes of bitterness, pungency and pepperiness are all typically assumed to be characteristics solely of GSLs or their ITCs. However some non-GSL derived compounds are known to contribute towards these perceptions [97]. For example, the presence of nitrile compounds in Nakajimana (B. rapa cv. nakajimana), a Japanese leafy vegetable, have been linked with pungent and bitter sensory attributes [98].

Three independent studies of rocket salad VOCs have reported tetrahydrothiophene as a pungent odourant of rocket $[30,88,99]$. Raffo et al. [88] described the compound as having a 'gaslike' odour, and Bell et al. [30] observed strong correlations of this compound with sensory descriptive attributes such as 'burnt rubber' odour, as well as with perceptions of heat, tingling, and bitter taste. It is unknown how this compound is synthesised in planta, but a synthetic version of the compound is used routinely as an odourant in the gas industry because of its strong aroma [100]. It may be an ITC degradation product, but this has not been demonstrated experimentally.

\subsection{Sulfides}

Off-odours, such as "sulfurous", "earthy", or "musty" are often attributed to Brassicaceae crops and GSL/ITC content [65]. These traits predominantly stem from sulfur-compound degradation products, such as from S-methyl-L-cysteine sulfoxide (SMCSO) [64], and formation can be facilitated by factors such as bacterial metabolism, plant senescence, cooking, and enzymatic breakdown as a result of tissue damage (e.g. cutting) [101-103].

This article is protected by copyright. All rights reserved. 
Sulfides are generally undesirable flavour attributes [82], and compounds like methanethiol, dimethyl sulfide (DMS), dimethyl trisulfide (DMTS), and dimethyl disulfide (DMDS) are regularly linked with sulfurous aromas and over-cooked off-flavours [40, 104, 105]. DMTS is produced during cooking of cauliflower and other Brassica varieties, and is likely to be greater in cultivars with high sulfur content [40]. These compounds are particularly problematic in Brassicaceae foods because they are detectable by humans at very low concentrations (0.02 ppb) [106]. Methanethiol has been noted for its presence in anaerobic atmospheres, and its formation is potentially promoted when modified atmospheric packaging (MAP) is used for preparing bagged salads and leafy Brassicas. For cooked Brassicas the amount of sulfur volatiles formed is highly dependent upon duration, temperature, and total tissue water content [103]. Storage and processing conditions post harvest are also likely to impact the abundance and types of VOCs, GSLs and ITCs produced [107], and therefore the relative abundance of sulfides.

GSLs and SMCSO in Brassica species both rely on available sulfur for their formation. As mentioned previously, the GSL glucoraphanin has been bred to have greater concentrations in new cultivars of broccoli, such as Beneforté. This up-regulation of GSL formation competes with SMCSO for sulfur; hence an increase in the proportion of sulfur allocated to methionine-derived glucosinolates results in a decrease in that allocated to SMCSO [57]. It is perhaps unsurprising therefore that such high GSL broccoli has proved acceptable to consumers, as neither glucoraphanin nor sulforaphane are bitter-tasting compounds, and such varieties could theoretically result in less sulfide generation. This has not been explicitly tested in this variety, however, and the concentrations of sulfides produced are still likely to exceed the minimum detection threshold.

\subsection{Thiocyanates}

GSLs produce diverse hydrolysis products, but very few other than ITCs have been sensorially characterised or studied in great detail. Some Brassicaceae produce thiocyanates as a GSL hydrolysis product, as well as ITCs. Plants such as the aptly named stinkweed (Thlaspi arvense), and landcress

This article is protected by copyright. All rights reserved. 
(Coronopus didymus), produce these off-smelling compounds as a defense strategy against herbivory [108].

Allyl thiocyanate (ATC) is another of the hydrolysis products of sinigrin. Chin et al. [109] reported that it was problematic to determine the odour characteristics of ATC because it is relatively unstable, and difficult to separate from AITC; during authentic compound synthesis distillation conditions, ATC readily converts to AITC. They were however able to determine the odour of ATC as musty, sulfurous and mustard-like. Relatively little else is known about these compounds and their effects upon odours within commercial crops.

\section{Modification of taste and flavour profiles through cooking}

As emphasized in the introduction, processing substantially modifies taste and flavour profiles of Brassica vegetables. The respective thermal stabilities of myrosinase and the specifier proteins are of key importance. As discussed earlier, there are a variety of end products that can result from GSL hydrolysis. Where myrosinase enzyme and ESP are both intact, there is a tendency for greater nitrile production and reduced ITC production; the reverse occurs where ESP is denatured but myrosinase remains intact. For example, in broccoli, ESP stimulates glucoraphanin conversion towards sulforaphane nitrile at the expense sulforaphane [6]. It is unknown how nitrile formation impacts taste and flavor, if at all, in major crops.

Thermal stability of myrosinase and ESP is reported to vary in different Brassica varieties and between cultivars $[110,111]$, however ESP is generally denatured at lower temperatures compared to myrosinase $[6,110]$. Therefore, in cases with mild cooking conditions there can be a greater concentration of resulting ITC than in the raw, macerated plant; but under more typical cooking conditions (e.g. boiling or steaming) both ESP and myrosinase may be denatured, resulting in intact GSL being present in the cooked product but few hydrolysis products. Cooking will also affect the generation of sulfur volatiles, and the characteristic sulfurous odour of cooked Brassica (e.g.

This article is protected by copyright. All rights reserved. 
boiled cabbage) that results from the release of sulfides, such as DMS. No published research has been conducted to determine how ITC-nitrile ratios influence taste, flavour and consumer acceptance of Brassica cultivars. Further investigation of cooking practices to optimise both nutritional and sensory quality of Brassica types is needed.

\section{Modification of taste and flavour profiles through breeding}

Taste and flavour profiles can be modified through selective breeding, but this often comes at the expense of nutritional health benefits [50]. There is renewed focus for breeding Brassicaceae crops with greater GSL content, whilst maintaining consumer acceptability. This must be approached cautiously, as focus on only one particular set of compounds (such as only GSLs) may bias interpretations of sensory-chemical data.

It would be prudent for breeding efforts to determine the ITC profile and myrosinase activity of cultivars in combination with the abundance of free sugars, VOCs, and (possibly) amino acids to modify taste and flavour. This would be a wiser track than selecting plants only for milder taste, and naively assuming that ITC content would be unaffected in direct response to unchanged GSL content. In this way, both health benefits and sensory acceptability can be monitored and preserved, and eventually improved over several generations. The sensations of pungency and hotness are not a reliable indicator of the quantity of health beneficial ITCs present, as evidenced by the fact that some (such as SF) have no discernable flavour. Others may be masked by high relative sugar content, and there is a danger that sweetness is selected for at the expense of bitter and pungent ITCs, which are potentially health beneficial. It is also not sufficient to assume that GSL/ITC content will be preserved over generations if they are not constantly and quantitatively measured. This also applies across growing environments and climates, where changes to GSL biosynthesis (as well as other phytochemicals) can have a large impact upon taste, flavour, and pungency of Brassicales crops [35]. Breeding of Brassica plants to optimise GSL or ITC content must also consider how the plant will be

This article is protected by copyright. All rights reserved. 
processed before consumption. Accounting for all of these influencing factors is a considerable challenge, and requires large amounts of investment in both breeding programs and conducting the required phytochemical analyses.

Many papers highlighting the potential for breeding new cultivars with improved health benefits neglect the importance of co-selecting for taste and flavour attributes in tandem with phytochemical traits, which are arguably just as important. Many consumers will reject a product on the first instance of consumption if it does not taste good to them, no matter how "healthy" it is purported to be. This needs to be a fundamental consideration in breeding research efforts [112].

\section{Summary and conclusions}

It is generally accepted that many GSL compounds impart bitterness and many ITCs impart pungency. As has been discussed however, this is not universally applicable, and more detailed studies are needed to establish perception thresholds of isolated compounds. This will have to involve either the food-grade synthesis of compounds, or isolation from plant material. The latter option is likely to be the preferred method for non-expert chemists, and it would be desirable for food-grade standards to be commercially available from specialist suppliers. There is potentially a large market for such a service for these compounds.

If the isolated tastes and/or flavours can be experimentally determined (e.g. by taste extraction dilution analysis for non-volatiles, and GC-O for volatiles), this would allow a better understanding of their contribution to the sensory profiles of Brassicaceae vegetables, and why perceptions vary between cultivars. Individual ITCs have distinct aromas/flavours as highlighted in Table 1; but determining their relative contribution to a sensation in the whole food matrix has not been quantitatively performed. This would perhaps require quantitative reconstruction of an extract in a similar way to what has been achieved in wine [113]; but until stable food grade standards become more widely available, this will remain an unexplored area. Much more research is needed to 
characterise the sensory attributes of nitriles, thiocyanates, and indoles in different crop species, and how they affect taste and/or flavour.

The human olfactory system is far more sensitive than any GC-MS [73], hence employing the use of sensory and consumer panels in the development and research of crop varieties and cultivars for enhanced traits should be integral until more sophisticated approaches can be developed. Additionally, more fundamental research is required to understand the trigeminal and olfactory mechanisms responsible for ITC perception in humans.

It is also important not to conflate the sensory effects and contributions of GSLs and ITCs when conducting correlation analyses. GSLs are phytochemical precursors to many compounds, not just ITCs, and basing crop improvement choices solely upon GSL content is therefore not guaranteed to be indicative of downstream sensory perceptions generated by hydrolysis products. Selective breeding programs should take an informed and analytical approach when basing selections upon taste and flavour. Without chemical analysis, it is impossible to determine the ITC status of Brassicales crops, and breeders should endeavor to incorporate these into breeding programs wherever possible.

To complicate the picture further, the abundance of free sugars, free amino acids, sulfides, and phenolics also need to be accounted for in determining the taste and flavour of Brassicaceae and other GSL/ITC producing crops such as Moringa and Papaya. The effects imparted by sweet or bitter compounds within the food matrix is likely to depend greatly on the individual GSL/ITC profile of each respective species, and the relative bitterness/pungency they in turn produce. This interaction could be fundamental for producing new cultivars with both enhanced sensory and health-promoting properties in future.

This article is protected by copyright. All rights reserved. 


\section{References}

[1] Holst, B., Williamson, G., A critical review of the bioavailability of glucosinolates and related compounds. Nat. Prod. Rep. 2004, 21, 425-447.

[2] Agerbirk, N., Olsen, C.E., Glucosinolate structures in evolution. Phytochem. 2012, 77, 1645.

[3] Fahey, J.W., Zalcmann, A.T., Talalay, P., The chemical diversity and distribution of glucosinolates and isothiocyanates among plants. Phytochem. 2001, 56, 5-51.

[4] Kuchernig, J.C., Burow, M., Wittstock, U., Evolution of specifier proteins in glucosinolatecontaining plants. BMC Evol. Biol. 2012, 12, 127.

[5] Matusheski, N. V, Jeffery, E.H., Comparison of the bioactivity of two glucoraphanin hydrolysis products found in broccoli, sulforaphane and sulforaphane nitrile. J. Agric. Food Chem. 2001, 49, 5743-5749.

[6] Matusheski, N. V., Juvik, J.A., Jeffery, E.H., Heating decreases epithiospecifier protein activity and increases sulforaphane formation in broccoli. Phytochem. 2004, 65, 1273-1281.

[7] Halkier, B.A., Gershenzon, J., Biology and biochemistry of glucosinolates, in: Ann. Rev. Pl. Biol. 2006, pp. 303-333.

[8] Bonnema, G., Verkerk, R., Glucosinolates \& Beyond, in: 3rd Intl. Glucosinolate Conf. 2014, Wageningen Universtiy, Wageningen, Netherlands 2014.

[9] Drewnowski, A., Gomez-Carneros, C., Bitter taste, phytonutrients, and the consumer: a review. Am. J. Clin. Nutr. 2000, 72, 1424-1435.

[10] Dinkova-Kostova, A.T., Kostov, R. V., Glucosinolates and isothiocyanates in health and disease. Trends Mol. Med. 2012, 18, 337-347.

[11] Jakubikova, J., Bao, Y.P., Sedlak, J., Isothiocyanates induce cell cycle arrest, apoptosis and mitochondrial potential depolarization in HL-60 and multidrug-resistant cell lines. Anticancer Res. 2005, 25, 3375-3386.

[12] Sarkar, F.H., Li, Y.W., Indole-3-carbinol and prostate cancer. J. Nutr. 2004, 134, 3493S$3498 \mathrm{~S}$.

[13] Beaver, L.M., Kuintzle, R., Buchanan, A., Wiley, M.W., Glasser, S.T., Wong, C.P, Johnson, G.S., Chang, J.H., Löhr, C.V., Williams, D.E., Dashwood, R.H., Hendrix, D.A., Ho, E., Long noncoding RNAs and sulforaphane: a target for chemoprevention and suppression of prostate cancer. J. Nutr. Biochem. 2017, 42, 72-83.

[14] Hayes, J.D., Kelleher, M.O., Eggleston, I.M., The cancer chemopreventive actions of phytochemicals derived from glucosinolates. Eur. J. Nutr. 2008, 47, 73-88.

[15] Wu, C.-L., Huang, A.-C., Yang, J.-S., Liao, C.-L., Lu, H.-F., Chou, S.-T., Ma, C.-Y., Hsia, T.-C., Ko, Y.-C., Chung, J.-G., Benzyl isothiocyanate (BITC) and phenethyl isothiocyanate (PEITC)-mediated

This article is protected by copyright. All rights reserved. 
generation of reactive oxygen species causes cell cycle arrest and induces apoptosis via activation of caspase-3, mitochondria dysfunction and nitric oxide (NO) in human osteogenic. J. Orthop. Res. 2011, 29, 1199-1209.

[16] Melchini, A., Traka, M.H., Catania, S., Miceli, N., Taviano, F., Maimone, P., Francisco, M., Mithen, R.F., Costa, C., Antiproliferative activity of the dietary isothiocyanate erucin, a bioactive compound from cruciferous vegetables, on human prostate cancer cells. Nutr. Cancer 2013, 65, 132-138.

[17] Giacoppo, S., Galuppo, M., Montaut, S., Iori, R., Rollin, P., Bramanti, P., Mazzon, E., An overview on neuroprotective effects of isothiocyanates for the treatment of neurodegenerative diseases. Fitoterapia 2015, 106, 12-21.

[18] Shapiro, T.A., Fahey, J.W., Dinkova-Kostova, A.T., Holtzclaw, W.D., Stephenson, K.K., Wade, K.L., Ye, L., Talalay, P., Safety, tolerance, and metabolism of broccoli sprout glucosinolates and isothiocyanates: A clinical phase I study. Nutr. Cancer-an Int. J. 2006, 55, 53-62.

[19] Bell, L., Oruna-Concha, M.J., Wagstaff, C., Identification and quantification of glucosinolate and flavonol compounds in rocket salad (Eruca sativa, Eruca vesicaria and Diplotaxis tenuifolia) by LC-MS: highlighting the potential for improving nutritional value of rocket crops. Food Chem. 2015, 172, 852-861.

[20] Schonhof, I., Krumbein, A., Brückner, B., Genotypic effects on glucosinolates and sensory properties of broccoli and cauliflower. Food/Nahrung 2004, 48, 25-33.

[21] Baik, H.Y., Juvik, J., Jeffery, E.H., Wallig, M.A., Kushad, M., Klein, B.P., Relating glucosinolate content and flavor of broccoli cultivars. J. Food Sci. 2003, 68, 1043-1050.

[22] Fenwick, G.R., Griffiths, N.M., Heaney, R.K., Bitterness in brussels sprouts (Brassica oleracea L. var.gemmifera): The role of glucosinolates and their breakdown products. J. Sci. Food Agric. 1983, 34, 73-80.

[23] Zabaras, D., Roohani, M., Krishnamurthy, R., Cochet, M., Delahunty, C.M., Characterisation of taste-active extracts from raw Brassica oleracea vegetables. Food Funct. 2013, 4, 592.

[24] Elmore, J.S., Extraction techniques for analysis of aroma compounds, in: Parker, J.K., Elmore, J.S., Methven, L. (Eds.), Flavour Development, Analysis and Perception in Food and Beverages, 1st ed., Woodhead Publishing, 2014, pp. 31-46.

[25] Elmore, J.S., in: Parker, J.K., Elmore, J.S., Methven, L. (Eds.), Flavour Development, Analysis and Perception in Food and Beverages, Woodhead Publishing, 2014, pp. 47-61.

[26] Parker, J.K., in: Parker, J.K., Elmore, J.S., Methven, L. (Eds.), Flavour Development, Analysis and Perception in Food and Beverages, Woodhead Publishing, 2014, pp. 3-30.

[27] Ridgway, K., in: Parker, J.K., Elmore, J.S., Methven, L. (Eds.), Flavour Development, Analysis and Perception in Food and Beverages, Woodhead Publishing, 2014, pp. 63-81.

[28] Lawless, H.T., Heymann, H., (Eds.), Sensory Evaluation of Food, Springer New York, New York, NY, USA 2010.

This article is protected by copyright. All rights reserved. 
[29] Siegmund, B., in: Parker, J.K., Elmore, J.S., Methven, L. (Eds.), Flavour Development, Analysis and Perception in Food and Beverages, Woodhead Publishing, 2014, pp. 127-149.

[30] Bell, L., Methven, L., Signore, A., Jose Oruna-Concha, M., Wagstaff, C., Analysis of Seven Salad Rocket (Eruca sativa) Accessions: The Relationships Between Sensory Attributes and Volatile and Non-volatile Compounds. Food Chem. 2017, 218, 181-191.

[31] Wold, H., in: Kotz, S., Johnson, N. (Eds.), Encyclopedia of Statistical Sciences, John Wiley \& Sons, Inc., Hoboken, NJ, USA 2006, pp. 581-591.

[32] Frank, S., Wollmann, N., Schieberle, P., Hofmann, T., Reconstitution of the Flavor Signature of Dornfelder Red Wine on the Basis of the Natural Concentrations of Its Key Aroma and Taste Compounds. J. Agric. Food Chem. 2011, 59, 8866-8874.

[33] Prescott, J., Monteleone, E., in: Parker, J.K., Elmore, J.S., Methven, L. (Eds.), Flavour Development, Analysis and Perception in Food and Beverages, Woodhead Publishing, 2014, pp. 369-385.

[34] Methven, L., in: Parker, J.K., Elmore, J.S., Methven, L. (Eds.), Flavour Development, Analysis and Perception in Food and Beverages, Woodhead Publishing, 2014, pp. 353-368.

[35] Bell, L., Wagstaff, C., Enhancement Of Glucosinolate and Isothiocyanate Profiles In Brassicaceae Crops: Addressing Challenges In Breeding For Cultivation, Storage, and Consumer Related Traits. J. Agric. Food Chem. 2017, 65, 9379-9403.

[36] Cartea, M.E., Rodríguez, V.M., de Haro, A., Velasco, P., Ordás, A., Variation of glucosinolates and nutritional value in nabicol (Brassica napus pabularia group). Euphytica $2008,159,111-122$.

[37] Hanschen, F.S., Schreiner, M., Isothiocyanates, Nitriles, and Epithionitriles from Glucosinolates Are Affected by Genotype and Developmental Stage in Brassica oleracea Varieties. Front. Plant Sci. 2017, 8, 1095.

[38] Behrens, M., Foerster, S., Staehler, F., Raguse, J.-D., Meyerhof, W., Gustatory expression pattern of the human TAS2R bitter receptor gene family reveals a heterogenous population of bitter responsive taste receptor cells. J. Neurosci. 2007, 27, 12630-12640.

[39] Mennella, J.A., Pepino, M.Y., Duke, F.F., Reed, D.R., Age modifies the genotype-phenotype relationship for the bitter receptor TAS2R38. BMC Genet. 2010, 11, 60.

[40] Engel, E., Line Baty, C.Ä., Le Corre, D., Souchon, I., Martin, N., Flavor-Active Compounds Potentially Implicated in Cooked Cauliflower Acceptance. J. Agric. Food Chem. 2002, 50, 64596467.

[41] Kim, U.-K., Jorgenson, E., Coon, H., Leppert, M., Risch, N., Drayna, D., Positional cloning of the human quantitative trait locus underlying taste sensitivity to phenylthiocarbamide. Science 2003, 299, 1221-1225.

[42] Sandell, M.A., Breslin, P.A.S., Variability in a taste-receptor gene determines whether we taste toxins in food. Curr. Biol. 2006, 16.

This article is protected by copyright. All rights reserved. 
[43] Shen, Y., Kennedy, O.B., Methven, L., Exploring the effects of genotypical and phenotypical variations in bitter taste sensitivity on perception, liking and intake of brassica vegetables in the UK. Food Qual. Prefer. 2016, 50, 71-81.

[44] Hayes, J.E., Keast, R.S.J., Two decades of supertasting: Where do we stand? Physiol. Behav. 2011, 104, 1072-1074.

[45] Bell, L., Methven, L., Wagstaff, C., The influence of phytochemical composition and resulting sensory attributes on preference for salad rocket (Eruca sativa) accessions by consumers of varying TAS2R38 diplotype. Food Chem. 2017, 222, 6-17.

[46] Jones, R.B., Faragher, J.D., Winkler, S., A review of the influence of postharvest treatments on quality and glucosinolate content in broccoli (Brassica oleracea var. italica) heads. Postharvest Biol. Technol. 2006, 41, 1-8.

[47] Frandsen, H.B., Markedal, K.E., Martín-Belloso, O., Sánchez-Vega, R., Soliva-Fortuny, R., Sørensen, H., Sørensen, S., Sørensen, J.C., Effects Of Novel Processing Techniques On Glucosinolates And Membrane Associated Myrosinases In Broccoli. Polish J. Food Nutr. Sci. 2014, $64,17-25$.

[48] Pence, B.C., Buddingh, F., Yang, S.P., Multiple Dietary Factors in the Enhancement of Dimethylhydrazine Carcinogenesis: Main Effect of Indole-3-carbinol. J. Natl. Cancer Inst. 1986, 77, 269-276.

[49] Meyerhof, W., Batram, C., Kuhn, C., Brockhoff, A., Chudoba, E., Bufe, B., Appendino, G., Behrens, M., The molecular receptive ranges of human TAS2R bitter taste receptors. Chem. Senses 2010, 35, 157-70.

[50] Van Doorn, H.E., Development of vegetables with improved consumer quality: A case study in Brussels sprouts. PhD Thesis, University of Wageningen. 1999.

[51] Steinmetz, K.A., Potter, J.D., Vegetables, Fruit, and Cancer. 2. Mechanisms. Cancer Causes Control 1991, 2, 427-442.

[52] Pasini, F., Verardo, V., Cerretani, L., Caboni, M.F., D'Antuono, L.F., Rocket salad (Diplotaxis and Eruca spp.) sensory analysis and relation with glucosinolate and phenolic content. J. Sci. Food Agric. 2011, 91, 2858-2864.

[53] D'Antuono, L.F., Elementi, S., Neri, R., Glucosinolates in Diplotaxis and Eruca leaves: Diversity, taxonomic relations and applied aspects. Phytochem 2008, 69, 187-199.

[54] Ludikhuyze, L., Rodrigo, L., Hendrickx, M., The activity of myrosinase from broccoli (Brassica oleracea L. var. italica): Influence of intrinsic and extrinsic factors. J. Food Prot. 2000, 63, 400-403.

[55] Zhao, D.Y., Tang, J., Ding, X.L., Analysis of volatile components during potherb mustard (Brassica juncea, Coss.) pickle fermentation using SPME-GC-MS. Lwt-Food Sci. Technol. 2007, 40, 439-447.

This article is protected by copyright. All rights reserved. 
[56] Traka, M., Mithen, R., Glucosinolates, isothiocyanates and human health. Phytochem. Rev. $2009,8,269-282$.

[57] Traka, M.H., Saha, S., Huseby, S., Kopriva, S., Walley, P.G., Barker, G.C., Moore, J., Mero, G., van den Bosch, F., Constant, H., Kelly, L., Schepers, H., Boddupalli, S., Mithen, R.F., Genetic regulation of glucoraphanin accumulation in Beneforté broccoli. New Phytol. 2013, 198, 108595.

[58] Jordt, S.-E., Bautista, D.M., Chuang, H., McKemy, D.D., Zygmunt, P.M., Högestätt, E.D., Meng, I.D., Julius, D., Mustard oils and cannabinoids excite sensory nerve fibres through the TRP channel ANKTM1. Nature 2004, 427, 260-265.

[59] Agrawal, A.A., Kurashige, N.S., A role for isothiocyanates in plant resistance against the specialist herbivore Pieris rapae. J. Chem. Ecol. 2003, 29, 1403-1415.

[60] Sultana, T., Savage, G.P., McNeil, D.L., Porter, G.P., Clark, B., Comparison of flavour compounds in wasabi and horseradish. J. Food Agric. Environ. 2003, 1, 117-121.

[61] Agneta, R., Möllers, C., Rivelli, A.R., Horseradish (Armoracia rusticana), a neglected medical and condiment species with a relevant glucosinolate profile: a review. Genet. Resour. Crop Evol. 2013, 60, 1923-1943.

[62] Depree, J.A., Howard, T.M., Savage, G.P., Flavour and pharmaceutical properties of the volatile sulphur compounds of Wasabi (Wasabia japonica). Food Res. Int. 1999, 31, 329-337.

[63] D’Auria, M.; Mauriello, G.. R., SPME-GC-MS analysis of horseradish (Armoracia rusticana) [solid-phase microextraction-gas chromatography-mass spectrometry]. Ital. J. Food Sci. 2004.

[64] Ghawi, S.K., Shen, Y., Niranjan, K., Methven, L., Consumer acceptability and sensory profile of cooked broccoli with mustard seeds added to improve chemoprotective properties. J. Food Sci. 2014, 79, S1756-S1762.

[65] Chen, W., Karangwa, E., Yu, J., Xia, S., Feng, B., Zhang, X., Jia, C., Characterizing red radish pigment off-odor and aroma-active compounds by sensory evaluation, gas chromatographymass spectrometry/olfactometry and partial least square regression. Food Bioprocess Technol. 2017, 10, 1-17.

[66] Suzuki, C., Ohnishi-Kameyama, M., Sasaki, K., Murata, T., Yoshida, M., Behavior of glucosinolates in pickling cruciferous vegetables. J. Agric. Food Chem. 2006, 54, 9430-9436.

[67] Coogan, R.C., Wills, R.B.H., Nguyen, V.Q., Pungency levels of white radish (Raphanus sativus L.) grown in different seasons in Australia. Food Chem. 2001, 72, 1-3.

[68] Wills, R.B.H., Coogan, R.C., Cultural Differences In Degree Of Liking Of Asian White Radish (Raphanus sativus L.). J. Sens. Stud. 2003, 18, 83-87.

[69] Khataan, N.H., Stewart, L., Brenner, D.M., Cornelis, M.C., et al., TAS2R38 genotypes and phenylthiocarbamide bitter taste perception in a population of young adults. J. Nutrigenet. Nutrigenomics 2009, 2, 251-256.

This article is protected by copyright. All rights reserved. 
[70] Fowke, J.H., Chung, F.L., Jin, F., Qi, D., Cai, Q., Conaway, C., Cheng, J.-R., Shu, X.-O., Gao, Y.T., Zheng, W., Urinary isothiocyanate levels, Brassica, and human breast cancer. Cancer Res. 2003, 63, 3980-3986.

[71] Possenti, M., Baima, S., Raffo, A., Durazzo, A., Giusti, A.M., Natella, F., in: Glucosinolates, Springer International Publishing, Cham, Switzerland 2016, pp. 1-46.

[72] Palaniswamy, U.R., Watercress: A Salad Crop with Chemopreventive Potential. Horttechnology 2001, 11, 622-626.

[73] Reed, D.R., Knaapila, A., Genetics of taste and smell: poisons and pleasures. Prog. Mol. Biol. Transl. Sci. 2010, 94, 213-40.

[74] Jaeger, S.R., McRae, J.F., Bava, C.M., Beresford, M.K., Hunter, D., Jia, Y., Chheang, S.L., Jin, D., Peng, M, Gamble, J.C., Atkinson, K.R., Axten, L.G., Paisley, A.G., Tooman, L., Pineau, B., Rouse, S.A., Newcomb, R.D., A mendelian trait for olfactory sensitivity affects odor experience and food selection. Curr. Biol. 2013, 23, 1601-1605.

[75] McRae, J.F., Mainland, J.D., Jaeger, S.R., Adipietro, K.A., Matsunami, H., Newcomb, R.D., Genetic variation in the odorant receptor OR2J3 is associated with the ability to detect the "grassy" smelling odor, cis-3-hexen-1-ol. Chem. Senses 2012, 37, 585-593.

[76] Keller, A., Zhuang, H., Chi, Q., Vosshall, L.B., Matsunami, H., Genetic variation in a human odorant receptor alters odour perception. Nature 2007, 449, 468-472.

[77] Hasin, Y., Olender, T., Khen, M., Gonzaga-Jauregui, C., Kim, P.M., Urban, A.E., Snyder, M., Gerstein, M.B., Lancet, D., Korbel, J.O., High-resolution copy-number variation map reflects human olfactory receptor diversity and evolution. PLoS Genet. 2008, 4.

[78] Buck, L., Axel, R., A novel multigene family may encode odorant receptors: A molecular basis for odor recognition. Cell 1991, 65, 175-187.

[79] Jin, J., Koroleva, O.A., Gibson, T., Swanston, J., Magan, J., Zhang, Y., Rowland, I.R., Wagstaff, C., Analysis of Phytochemical Composition and Chemoprotective Capacity of Rocket (Eruca sativa and Diplotaxis tenuifolia) Leafy Salad Following Cultivation in Different Environments. J. Agric. Food Chem. 2009, 57, 5227-5234.

[80] Voutsina, N., Payne, A.C., Hancock, R.D., Clarkson, G.J.J., Rothwell, S.D., Chapman, M.A., Taylor, G., Characterization of the watercress (Nasturtium officinale R. Br.; Brassicaceae) transcriptome using RNASeq and identification of candidate genes for important phytonutrient traits linked to human health. BMC Genomics 2016, 17, 378.

[81] Freeman, G.G., Mossadeghi, N., Influence of Sulphate Nutrition on Flavour Components of Three Cruciferous Plants : Radish (Raphanus sativus), Cabbage (Brassica oleracea capitata) and White Mustard (Sinapis alba). J. Sci. Food Agric. 1972, 23, 387-402.

[82] Hansen, M., Laustsen, A.M., Olsen, C.E., Poll, L., Sørensen, H., Chemical and sensory quality of broccoli (Brassica oleracea L. var italica). J. Food Qual. 1997, 20, 441-459.

This article is protected by copyright. All rights reserved. 
[83] Sansom, C.E., Jones, V.S., Joyce, N.I., Smallfield, B.M., Perry, N.B., van Klink, J.W., Flavor, glucosinolates, and isothiocyanates of nau (Cooks scurvy grass, Lepidium oleraceum) and other rare New Zealand Lepidium species. J. Agric. Food Chem. 2015, 63, 1833-1838.

[84] Abe, K., Kido, S., Maeda, T., Kami, D., Matsuura, H., Shimura, H., Suzuki, T., Glucosinolate profiles in Cardamine fauriei and effect of light quality on glucosinolate concentration. Sci. Hortic. (Amsterdam). 2015, 189, 12-16.

[85] Bennett, R.N., Carvalho, R., Mellon, F.A., Eagles, J., Rosa, E.A.S., Identification and quantification of glucosinolates in sprouts derived from seeds of wild Eruca sativa L. (salad rocket) and Diplotaxis tenuifolia L. (wild rocket) from diverse geographical locations. J. Agric. Food Chem. 2007, 55, 67-74.

[86] Bennett, R.N., Mellon, F.A., Botting, N.P., Eagles, J., Rosa, E.A.S., Williamson, G., Identification of the major glucosinolate (4-mercaptobutyl glucosinolate) in leaves of Eruca sativa L. (salad rocket). Phytochem. 2002, 61, 25-30.

[87] Bell, L., Spadafora, N.D., Müller, C.T., Wagstaff, C., Rogers, H.J., Use of TD-GC-TOF-MS to assess volatile composition during post-harvest storage in seven accessions of rocket salad (Eruca sativa). Food Chem. 2016, 194, 626-636.

[88] Raffo, A., Masci, M., Moneta, E., Nicoli, S., del Pulgar, J.S., Paoletti, F., Characterization of volatiles and identification of odor-active compounds of rocket leaves. Food Chem. 2018, 240, 1161-1170.

[89] Cerny, M.S., Taube, E., Battaglia, R., Identification of bis(4-isothiocyanatobutyl) disulfide and its precursor from Rocket salad (Eruca sativa). J. Agric. Food Chem. 1996, 44, 3835-3839.

[90] Sultana, T., Savage, G.P., McNeil, D.L., Porter, N.G., Martin, R.J., Deo, B., Effects of fertilisation on the allyl isothiocyanate profile of above-ground tissues of New Zealand-grown wasabi. J. Sci. Food Agric. 2002, 82, 1477-1482.

[91] Levine, L.H., Bisbee, P.A., Richards, J.T., Birmele, M.N., Prior, R.L., Perchonok, M., Dixon, M., Yorio, N.C., Stutte, G.W., Wheeler, R.M., Quality characteristics of the radish grown under reduced atmospheric pressure. Adv. Sp. Res. 2008, 41, 754-762.

[92] Padilla, G., Cartea, M.E., Velasco, P., de Haro, A., Ordás, A., Variation of glucosinolates in vegetable crops of Brassica rapa. Phytochem. 2006, 68, 536-545.

[93] Kirimura, J., Shimizu, A., Kimizuka, A., Ninomiya, T., Katsuya, N., Contribution of peptides and amino acids to the taste of foods. J. Agric. Food Chem. 1969, 17, 689-695.

[94] Nishimura, T., Kato, H., Taste of free amino acids and peptides. Food Rev. Int. 1988, 4, 175-194.

[95] Park, S., Arasu, M. V, Lee, M.-K., Chun, J.-H., Seo, J.M., Lee, S.-W., Al-Dhabi, N.A., Kim, S.-J., Quantification of glucosinolates, anthocyanins, free amino acids, and vitamin $\mathrm{C}$ in inbred lines of cabbage (Brassica oleracea L.). Food Chem. 2014, 145, 77-85.

This article is protected by copyright. All rights reserved. 
[96] Fukuda, T., Okazaki, K., Watanabe, A., Shinano, T., Oka, N., GC-MS based metabolite profiling for flavor characterization of Brassica crops grown with different fertilizer application. Metabolomics 2015, 12, 20.

[97] Hanschen, F.S., Lamy, E., Schreiner, M., Rohn, S., Reactivity and Stability of Glucosinolates and Their Breakdown Products in Foods. Angew. Chemie Int. Ed. 2014, 53, 11430-11450.

[98] Kato, M., Imayoshi, Y., Iwabuchi, H., Shimomura, K., Kinetic changes in glucosinolatederived volatiles by heat-treatment and myrosinase activity in nakajimana (Brassica rapa L. cv. nakajimana). J. Agric. Food Chem. 2011, 59, 11034-9.

[99] Jirovetz, L., Smith, D., Buchbauer, G., Aroma compound analysis of Eruca sativa (Brassicaceae) SPME headspace leaf samples using GC, GC-MS, and olfactometry. J. Agric. Food Chem. 2002, 50, 4643-4646.

[100] Swanston, J., Ullmann's Encyclopedia of Industrial Chemistry, Wiley-VCH Verlag GmbH \& Co. KGaA, Weinheim, Germany 2000.

[101] Stoewsand, G.S., Bioactive Organosulfur Phytochemicals in Brassica oleracea Vegetables - a Review. Food Chem. Toxicol. 1995, 33, 537-543.

[102] Palermo, M., Pellegrini, N., Fogliano, V., The effect of cooking on the phytochemical content of vegetables. J. Sci. Food Agric. 2014, 94, 1057-70.

[103] Kubec, R., Drhová, V., Velíšek, J., Thermal Degradation of S-Methylcysteine and Its Sulfoxide Important Flavor Precursors of Brassica and Allium Vegetables. J. Agric. Food Chem. 1998, 46, 4334-4340.

[104] Hansen, M., Buttery, R.G., Stern, D.J., Cantwell, M.I., Ling., L.C., Broccoli storage under low-oxygen atmosphere: identification of higher boiling volatiles. J. Agric. Food Chem. 1992, 40, 850-852.

[105] Chin, H.-W., Lindsay, R.C., Volatile Sulfur Compounds Formed in Disrupted Tissues of Different Cabbage Cultivars. J. Food Sci. 1993, 58, 835-839.

[106] Lindsay, R.C., Rippe, J.K., Enzymic Generation of Methanethiol To Assist in the Flavor Development of Cheddar Cheese and Other Foods, in: Biogeneration of Aromas, 1986, pp. 286308.

[107] Rangkadilok, N., Tomkins, B., Nicolas, M.E., Premier, R.R., Bennett, R.N., Eagling, D.R., Taylor, P.W.J., The effect of post-harvest and packaging treatments on glucoraphanin concentration in broccoli (Brassica oleracea var. italica). J. Agric. Food Chem. 2002, 50, 73867391.

[108] Fenwick, G.R., Heaney, R.K., Glucosinolates and their breakdown products in cruciferous crops, foods and feedingstuffs. Food Chem. 1983, 11, 249-271.

[109] Chin, H.-W., Zeng, Q., Lindsay, R.C., Occurrence and Flavor Properties of Sinigrin Hydrolysis Products in Fresh Cabbage. J. Food Sci. 1996, 61, 101-104.

This article is protected by copyright. All rights reserved. 
[110] Ghawi, S.K., Methven, L., Niranjan, K., The potential to intensify sulforaphane formation in cooked broccoli (Brassica oleracea var. italica) using mustard seeds (Sinapis alba). Food Chem. 2013, 138, 1734-1741.

[111] Okunade, O.A., Ghawi, S.K., Methven, L., Niranjan, K., Thermal and pressure stability of myrosinase enzymes from black mustard (Brassica nigra L. W.D.J. Koch. var. nigra), brown mustard (Brassica juncea L. Czern. var. juncea) and yellow mustard (Sinapis alba L. subsp. maire) seeds. Food Chem. 2015, 187, 485-490.

[112] Ishida, M., Hara, M., Fukino, N., Kakizaki, T., Morimitsu, Y., Glucosinolate metabolism, functionality and breeding for the improvement of Brassicaceae vegetables. Breed. Sci. 2014, 64, 48-59.

[113] Hufnagel, J.C., Hofmann, T., Quantitative Reconstruction of the Nonvolatile Sensometabolome of a Red Wine. J. Agric. Food Chem. 2008, 56, 9190-9199.

\section{Figure legend}

Figure 1. The glucosinolate-myrosinase reaction produces numerous and diverse hydrolysis products, including epithionitriles, thiocyanates, isothiocyanates (ITCs), nitriles, and oxazolidines. These products are influenced by many factors, including: ambient temperature, $\mathrm{pH}$, and the presence of enzyme co-factors (e.g. ESP, TFP, \& NSP). Glucosinolate (GSL) compounds can have a bitter taste, and oxazolidines (such as goitrin) impart extreme bitterness. Isothiocyanate compounds are responsible for some bitterness (e.g. sinigrin), but primarily for the hot, pungent, and lachrymose sensations that are typified by mustards, rocket, watercress, horseradish, and wasabi. Some ITCs are not known to impart strong flavour (e.g. erucin), whereas others have not been previously described. This figure presents the chemical structures of ITCs present within commonly consumed Brassicales species. The name of the precursor GSL is given in brackets, and bold numbers refer to those assigned in Fahey et al. and Agerbirk \& Olsen. Sensory descriptors for each compound are described in Table 1.

This article is protected by copyright. All rights reserved. 
Figure 2. Sensorial detection of glucosinolates (GSLs), isothiocyanates (ITCs), and sulfur containing volatile organic compounds (SVOCs) by the human nervous system. Glucosinolate compounds are exclusively detected upon the tongue, predominantly by TAS2R bitter taste receptors such as TAS2R38, upon ingestion. The action of mastication breaks plant tissues and brings GSLs and myrosinase enzymes into contact, releasing hydrolysis products that include ITCs. Many of these compounds are volatile and interact with ANKTM1 TRP ion channels to infer pungency within mucosal membranes in the mouth, nose and throat. Olfactory receptors also perceive ITCs and SVOCs, producing aromas characteristic of mustard, rocket, radish and cabbage. Other classes of compound are also likely to produce odours and flavours associated with Brassicaceae, Caricaceae, and Moringaceae crops, such as sulfides, SVOCs, as well as nitriles.
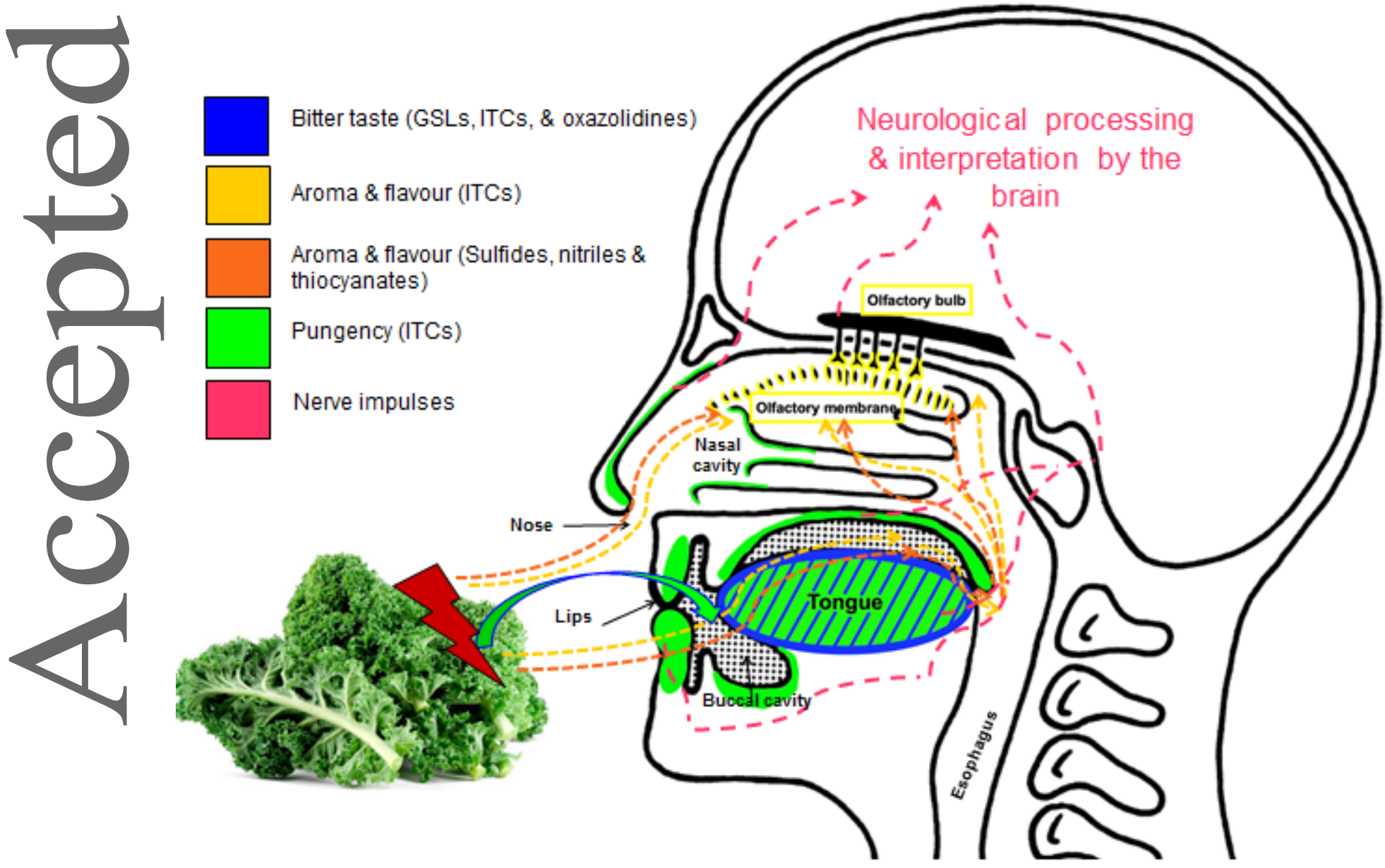

This article is protected by copyright. All rights reserved. 
Graphic Abstract

- Brassicaceae plants are bitter tasting with sulfurous aroma and pungency

- Responsible compounds: glucosinolates (GSLs), isothiocyanates (ITCs), and sulfurcontaining volatile compounds (SVOCs, such as sulfides).

- Specific GSLs impart bitterness and many ITCs impart pungency

- Some Brassicaceae plants are consumed raw whilst others are cooked

- Cooking effects hydrolysis of GSLs, plusmgeneration and release of sulfides

- In breeding new plant varieties it is prudent to consider the individual GSLs, the typical cooking conditions the plant is subjected to, enzyme stability and resultant composition of both GSL hydrolysis products (including ITCs) and sulfides.

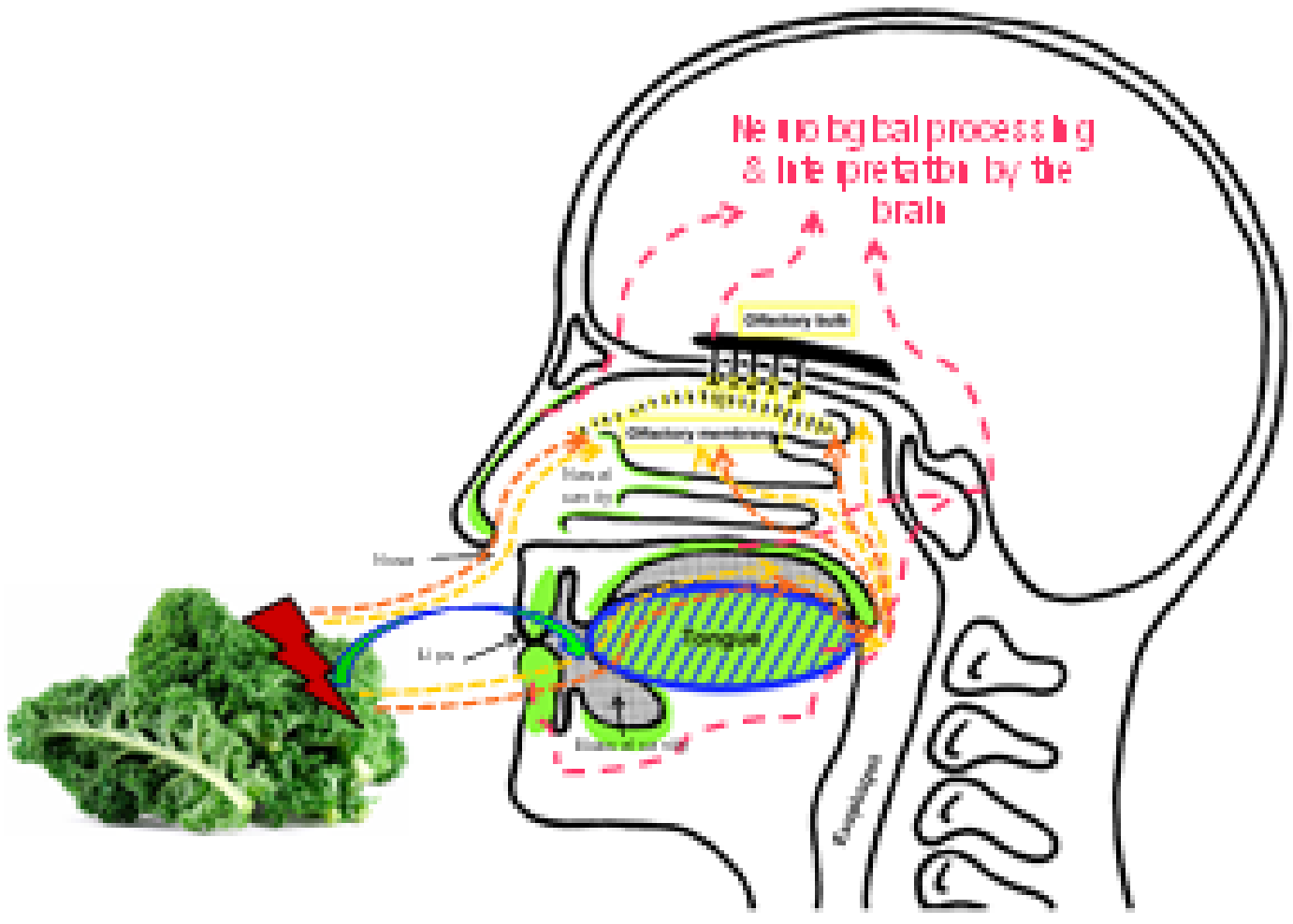

Bitter taste (GSLS, ITCS, \& oxazolidines)

Aroma $\&$ flavour (ITCs)

Aroma \& flavour (sulfides, nitriles

B. thiocyanates)

Pungency (ITCs)

Nerve impulses

This article is protected by copyright. All rights reserved. 
Table 1. Commonly reported glucosinolate and isothiocyanate compounds from plants within the Brassicales family, and their associated tastes, aromas and trigeminal sensations. Taste and trigeminal descriptors from isolation of either pure compounds and/or aroma descriptors according to GC-O analyses.

\begin{tabular}{|c|c|c|c|c|c|c|c|}
\hline Glucosinolate & $\begin{array}{l}\text { Sensory } \\
\text { Descript } \\
\text { or }\end{array}$ & & $\begin{array}{l}\text { Hydrolysis } \\
\text { Product }\end{array}$ & $\begin{array}{l}\text { Sensory } \\
\text { Descripto } \\
\mathrm{r}\end{array}$ & $\begin{array}{l}\text { Commonl } \\
y \text { found in }\end{array}$ & $\begin{array}{l}\text { Health } \\
\text { beneficial / } \\
\text { toxic effects }\end{array}$ & $\begin{array}{l}\text { Referen } \\
\text { ces }\end{array}$ \\
\hline \multirow[t]{2}{*}{ Sinigrin } & $\begin{array}{l}\text { Bitter } \\
\text { taste }\end{array}$ & $\rightarrow$ & Allyl ITC & $\begin{array}{l}\text { Bitter } \\
\text { taste, } \\
\text { pungent, } \\
\text { sulfurous, } \\
\text { mustard- } \\
\text { like, } \\
\text { lachrymo } \\
\text { se, } \\
\text { horseradi } \\
\text { sh-like }\end{array}$ & $\begin{array}{l}\text { Brown } \\
\text { mustard, } \\
\text { Horseradi } \\
\text { sh, } \\
\text { Cabbage }\end{array}$ & $\begin{array}{l}\text { Induces cell } \\
\text { cycle arrest } \\
\text { \& apoptosis } \\
\text { in drug } \\
\text { resistant } \\
\text { cancer cell } \\
\text { lines }\end{array}$ & $\begin{array}{l}11,22 \\
40,50 \\
60,62 \\
65,99\end{array}$ \\
\hline & & & $\begin{array}{l}\text { Allyl } \\
\text { thiocyanate }\end{array}$ & $\begin{array}{l}\text { Musty, } \\
\text { sulfurous, } \\
\text { mustard- } \\
\text { like }\end{array}$ & Cabbage & $\begin{array}{l}\text { Unknown } \\
\text { specific } \\
\text { effects }\end{array}$ & \\
\hline Gluconapin & $\begin{array}{l}\text { Bitter } \\
\text { taste }\end{array}$ & $\rightarrow$ & $\begin{array}{l}\text { 3-butenyl } \\
\text { ITC }\end{array}$ & $\begin{array}{l}\text { Pungent, } \\
\text { 'green', } \\
\text { wasabi- } \\
\text { like } \\
\text { flavour \& } \\
\text { heat, } \\
\text { vegetable- } \\
\text { like, } \\
\text { cabbage- } \\
\text { like }\end{array}$ & $\begin{array}{l}\text { Cook's } \\
\text { Scurvy } \\
\text { grass, } \\
\text { Brussels } \\
\text { sprouts, } \\
\text { Brown } \\
\text { mustard, } \\
\text { Broccoli, } \\
\text { Kale }\end{array}$ & $\begin{array}{l}\text { Unknown } \\
\text { specific } \\
\text { effects }\end{array}$ & $\begin{array}{l}22,23 \\
60,62 \\
83,86\end{array}$ \\
\hline Epi/Progoitrin & $\begin{array}{l}\text { Bitter } \\
\text { taste }\end{array}$ & $\rightarrow$ & Goitrin & $\begin{array}{l}\text { Extreme } \\
\text { bitter } \\
\text { taste }\end{array}$ & $\begin{array}{l}\text { Brussels } \\
\text { sprouts, } \\
\text { Salad } \\
\text { rocket, } \\
\text { Sea kale, } \\
\text { Turnips }\end{array}$ & $\begin{array}{l}\text { Potentially } \\
\text { toxic; may } \\
\text { induce } \\
\text { goiter in } \\
\text { thyroid } \\
\text { impaired or } \\
\text { iodine } \\
\text { deficient } \\
\text { individuals }\end{array}$ & $\begin{array}{l}22,50, \\
51\end{array}$ \\
\hline Glucobrassicin & Bitter & $\rightarrow$ & Indole-3- & "Unpleasa & Chinese & Has been & 12,22 \\
\hline
\end{tabular}

This article is protected by copyright. All rights reserved. 


\begin{tabular}{|c|c|c|c|c|c|c|c|}
\hline $\begin{array}{l}\text { / } \\
\text { Neoglucobrassi } \\
\text { cin }\end{array}$ & taste & & carbinol & nt" taste & $\begin{array}{l}\text { cabbage, } \\
\text { Broccoli, } \\
\text { Green } \\
\text { cabbage, } \\
\text { Red } \\
\text { cabbage }\end{array}$ & $\begin{array}{l}\text { shown to } \\
\text { inhibit } \\
\text { prostate } \\
\text { cancer }\end{array}$ & \\
\hline Glucoraphanin & $\begin{array}{l}\text { No } \\
\text { taste? }\end{array}$ & $\rightarrow$ & $\begin{array}{l}\text { Sulforapha } \\
\text { ne }\end{array}$ & $\begin{array}{l}\text { No taste } \\
\text { or } \\
\text { flavour? }\end{array}$ & $\begin{array}{l}\text { Broccoli, } \\
\text { Salad } \\
\text { rocket }\end{array}$ & $\begin{array}{l}\text { Prevents and } \\
\text { suppresses } \\
\text { cancer } \\
\text { formation; } \\
\text { effective } \\
\text { against } \\
\text { human } \\
\text { prostate } \\
\text { cancer }\end{array}$ & $\begin{array}{l}13,30, \\
45\end{array}$ \\
\hline $\begin{array}{l}\text { Glucotropaeoli } \\
\mathrm{n}\end{array}$ & $?$ & $\rightarrow$ & Benzyl ITC & Pungent & $\begin{array}{l}\text { Garden } \\
\text { cress, } \\
\text { Nasturtiu } \\
\text { m, } \\
\text { Papaya }\end{array}$ & $\begin{array}{l}\text { Induces } \\
\text { phase II } \\
\text { detoxificatio } \\
\text { n enzymes in } \\
\text { human } \\
\text { bladder and } \\
\text { bone cancer } \\
\text { cell lines }\end{array}$ & $\begin{array}{l}14,15, \\
60\end{array}$ \\
\hline Gluconasturtiin & $?$ & $\rightarrow$ & $\begin{array}{l}\text { Phenethyl } \\
\text { ITC }\end{array}$ & $\begin{array}{l}\text { Pungent, } \\
\text { radish- } \\
\text { like, } \\
\text { watercres } \\
\text { s-like, } \\
\text { produces } \\
\text { a 'tingling' } \\
\text { sensation }\end{array}$ & $\begin{array}{l}\text { Watercre } \\
\text { ss, } \\
\text { Horseradi } \\
\text { sh, } \\
\text { Wasabi }\end{array}$ & $\begin{array}{l}\text { Causes cell } \\
\text { cycle arrest } \\
\text { and } \\
\text { apoptosis in } \\
\text { human bone } \\
\text { cancer cell } \\
\text { lines }\end{array}$ & $\begin{array}{l}15,50, \\
62\end{array}$ \\
\hline Glucocapparin & $?$ & $\rightarrow$ & Methyl ITC & $\begin{array}{l}\text { Horseradi } \\
\text { sh-like, } \\
\text { lachrymo } \\
\text { se, } \\
\text { pungent, } \\
\text { vegetable- } \\
\text { like }\end{array}$ & Capers & $\begin{array}{l}\text { Unknown } \\
\text { specific } \\
\text { effects }\end{array}$ & $\begin{array}{l}40,62, \\
65,86\end{array}$ \\
\hline & & & $\begin{array}{l}\text { Methyl } \\
\text { thiocyanate }\end{array}$ & Sulfurous & & & \\
\hline Glucoputranjivi & $?$ & $\rightarrow$ & Isopropyl & Mustard- & Wasabi & Unknown & 60,62 \\
\hline
\end{tabular}




\begin{tabular}{|c|c|c|c|c|c|c|c|}
\hline $\mathrm{n}$ & & & ITC & $\begin{array}{l}\text { like, } \\
\text { pungent }\end{array}$ & & $\begin{array}{l}\text { specific } \\
\text { effects }\end{array}$ & \\
\hline $\begin{array}{l}\text { Glucobrassican } \\
\text { apin }\end{array}$ & $?$ & $\rightarrow$ & $\begin{array}{l}\text { 4-pentenyl } \\
\text { ITC }\end{array}$ & $\begin{array}{l}\text { Acrid, } \\
\text { 'green', } \\
\text { pungent, } \\
\text { fragrant, } \\
\text { mustard- } \\
\text { like, } \\
\text { horseradi } \\
\text { sh-like }\end{array}$ & $\begin{array}{l}\text { Broccoli, } \\
\text { Rapeseed }\end{array}$ & $\begin{array}{l}\text { Unknown } \\
\text { specific } \\
\text { effects }\end{array}$ & $\begin{array}{l}60,62, \\
99\end{array}$ \\
\hline Glucosinalbin & $?$ & $\rightarrow$ & $\begin{array}{l}\text { 4- } \\
\text { hydroxybe } \\
\text { nzyl ITC }\end{array}$ & Pungent & $\begin{array}{l}\text { Maca, } \\
\text { White } \\
\text { mustard }\end{array}$ & $\begin{array}{l}\text { Unknown } \\
\text { specific } \\
\text { effects }\end{array}$ & 64 \\
\hline $\begin{array}{l}\text { Glucoraphasati } \\
\mathrm{n}\end{array}$ & $?$ & $\rightarrow$ & Raphasatin & Pungent & $\begin{array}{l}\text { Radish, } \\
\text { Spanish } \\
\text { black } \\
\text { radish, } \\
\text { Japanese } \\
\text { white } \\
\text { radish }\end{array}$ & $\begin{array}{l}\text { Unknown } \\
\text { specific } \\
\text { effects }\end{array}$ & 65 \\
\hline Glucosativin & $?$ & $\rightarrow$ & Sativin & $\begin{array}{l}\text { Rocket- } \\
\text { like }\end{array}$ & $\begin{array}{l}\text { Salad } \\
\text { rocket, } \\
\text { Wild } \\
\text { rocket }\end{array}$ & $\begin{array}{l}\text { Unknown } \\
\text { specific } \\
\text { effects }\end{array}$ & 86 \\
\hline Glucoiberverin & $?$ & $\rightarrow$ & Iberverin & $\begin{array}{l}\text { Radish- } \\
\text { like, } \\
\text { pungent }\end{array}$ & $\begin{array}{l}\text { Cabbage, } \\
\text { Broccoli }\end{array}$ & $\begin{array}{l}\text { Unknown } \\
\text { specific } \\
\text { effects }\end{array}$ & $\begin{array}{l}60,65, \\
86\end{array}$ \\
\hline Glucoerucin & $?$ & $\rightarrow$ & Erucin & $\begin{array}{l}\text { Radish- } \\
\text { like, } \\
\text { cabbage- } \\
\text { like }\end{array}$ & $\begin{array}{l}\text { Salad } \\
\text { rocket, } \\
\text { Radish, } \\
\text { Chinese } \\
\text { cabbage, } \\
\text { Wild } \\
\text { rocket }\end{array}$ & $\begin{array}{l}\text { Inhibits cell } \\
\text { proliferation } \\
\text { in prostate } \\
\text { and } \\
\text { adenocarcin } \\
\text { oma cell } \\
\text { lines }\end{array}$ & $\begin{array}{l}16,86, \\
99\end{array}$ \\
\hline
\end{tabular}

This article is protected by copyright. All rights reserved. 